\title{
Use of the DCP test for compaction control of staged dikes in mining tailings dams
}

\author{
Uso do ensaio DCP para controle de \\ compactação de alteamentos em \\ barragens de rejeitos de mineração
}

\author{
Lincoln Ribeiro Maia de Resende \\ PPGEM - UFOP \\ lincolnresende@yahoo.com.br \\ Waldyr Lopes de Oliveira Filho \\ PPGEM, DEMIN - UFOP \\ waldyr@em.ufop.br
}

Christianne de Lyra Nogueira

PPGEM, DEMIN - UFOP

chris@em.ufop.br

\section{Resumo}

Esse artigo descreve a utilização de um método alternativo de controle de qualidade na compactação de aterros em barragens de rejeitos de mineração. $\mathrm{O}$ procedimento faz uso de um penetrômetro, conhecido pela sigla DCP (Dynamic Cone Penetrometer), de maior emprego na construção de estradas (avaliação da qualidade de camadas de pavimento). Com esse aparelho, pode ser feita a medição de resistência das camadas superficiais de solos naturais ou compactados, incluindo os rejeitos arenosos de mineração, de forma rápida e eficaz. O instrumento foi utilizado com sucesso no acompanhamento do alteamento de uma barragem de rejeitos de minério de ferro no Quadrilátero Ferrífero, Estado de Minas Gerais, e os resultados mostraram uma efetiva densificação das camadas compactadas, porém de forma irregular no que tange à distribuição espacial no corpo da barragem. Além disso, o controle da compactação também foi feito com método tradicional do cilindro biselado, permitindo a comparação das duas técnicas.

Palavras-chave: Alteamento de aterros, barragens de rejeito, controle de compactação, DCP.

\begin{abstract}
An alternative method for quality control of earthworks in mining tailing dams is described in this article. It is composed by a penetrometer, known by the acronym DCP (Dynamic Cone Penetrometer), and is used primarily in road construction (quality assessment of pavement layers). With this apparatus, strength measurement of superficial layers of natural and compacted soils can be performed, including mine sand tailings, in a fast and efficient manner. The instrument was successfully used in the construction control of an iron ore mining tailings staged dam in the Quadrilatero Ferrifero, in Minas Gerais State, and the results showed distinctly effective densification of the embankment compacted layers, but with a sort of irregularity in their spatial distribution. In addition, field control using the traditional core-cutter method was also performed for comparison between both techniques.
\end{abstract}

Keywords: Raise of staged dikes, tailings dam, compaction control, DCP. 


\section{Introduction}

Tailings dams have become a subject of great importance nowadays for the mining industry and also for the nearby community, due to the size these structures have reached and consequent increase in damage potential for catastrophic results when failures occurs. Regarding safety, it is essential that tailings dams be firm and stable, thus the way and quality of their construction is of the utmost importance. Embankment quality and its persistency in the whole compacted fill are two features to be pursued in tailings dam construction.

The traditional way of guaranteeing this goal in compacted fills is by controlling the dry unit weight and water content of the recently compacted layers, as is done

\section{Materials and methods}

In this study, DCP and core-cutter tests were performed. Both methods were used with the same purpose: quality assessment of the earthwork construction of

\section{Dike construction method}

The construction of a tailings dam is commonly performed in stages, each stage consisting of a new dike built on top of the previous one. In the case presented here, upstream raising, the construction of the dike is atop a tailings beach created by hydraulic discharge of sand tailings from the embankment crest.

The construction process of a new dike starts by making provisions for the construction material, which is obtained from the tailings beach through digging, transporting, and accumulation (deposition) at the construction site. These operations in the case of this report were done simultaneously by a dozer scraping and pushing the beach tailings sand in a crosswise movement from the beach lake towards the dike crest.

\section{The DCP equipment}

During the dike construction, the DCP device was used to assess the compaction quality of the layers as they were being finished. The DCP, as it was pointed out earlier, can be seen as an instrument to assess the bearing capacity of superficial terrains and also to evaluate shear strength in soil profiles up to a depth of one meter. Its operation is easy and precise, with low cost which makes it a potential choice for in building foundations and in highway construction. Another technique specifies a construction method, which is tailored from test fill programs, where means are optimized (lift thickness, number of roller passes, water content placement, etc.) in order to obtain the required quality; this process is common in large fill projects. In the case of tailings dams, more specifically in the construction of staged dike, the ideal situation would be a combination of these specifications, with an expeditious but precise method of assessing fill quality and its spatial variability.

Within this context, a study was devised to show how a simple and robust device called DCP (acronym of Dynamic

a compacted fill. The DCP test is presented as an alternative compaction control procedure to the traditional core-cutter method in the raise of a staged dam. The
Compaction Penetrometer) can be used during construction for compaction control of an iron ore tailings dam, raised by the upstream method. Such apparatus belongs to the category of penetrometers and is commonly used in road construction (quality assessment of pavement layers). It can assess the shear strength of sand soils and other fill materials up until one meter, revealing the densification degree and the extent of homogeneity. Besides the DCP tests, densification and water content placement were also verified through the core-cutter technique for comparison and the results are shown herein. For completeness, basic geotechnical characterization was also performed and is presented.

tailings dam where the DCP was used is located in an area called the Quadrilatero Ferrifero, in the central part of the State of Minas Gerais, in Brazil.
The construction material accumulated at the construction site in the form of small piles was a quartzous fine silty sand with low water content (around 5 to 7\%). These piles were then leveled by the dozer spreading of the material and forming a loose, 300-400 $\mathrm{mm}$ thick layer within the new dike offset area. When the material was too dry, watering of the tailings was required before compaction, which was done by water trucks used for road dust control. Finally, layer compaction was achieved by the dozer passing on top of the leveled layers at least six times over the same location. The dozer was a Komatsu D61ex model.

Some additional comments are worth mentioning about the construction of the dike. For the raise of the dike, whose crest length was more than $300 \mathrm{~m}$, the beach area was divided in two parts whereby the operation of scrapping and pushing the sand material was performed only on one side of the beach while the other side was left for tailings discharge, generating material for future raise of that part of the dike. These operations occurred alternately on each side of the dike which allowed an equal rise of the dam without any interruptions for lack of material.

When the dike started taking shape and height, a hydraulic excavator was used to transfer the tailings accumulated in piles at the foot of the new dike to the work platform. In this case the dozer was used to build a ramp for movement between the tailings beach and dike in construction. other applications besides road construction. Facing the constraints of the currents practice of compaction control in tailings construction with the traditional core-cutter technique, a pioneering effort was made in trying to use the DCP in this new context.

The device as it is known these days has its origin in the works of Van Vuuren and Scala, and was later modified by the Transvaal Road Department (TRD - South Africa), resulting in the current design known worldwide (Kleyn, 1975). Figure 1 presents a DCP drawing and a photo of it in operation.

Structurally, DCP is a portable device made of three metal rods standing vertically when in use: two of them of the same height (before testing) in the lower part and the third one forming 
the upper part of the frame connected to one of the inferior ones by a coupling piece. The upper rod is used as a "guide" for an $8 \mathrm{~kg}$ dead weight that is loosened during the test, hitting the coupling piece that also works as a hitting head. The blows generate enough force to penetrate one of the inferior rods. The other inferior rod is fixed and set on the soil surface holding a ruler (with millimeter readings) which measures rod penetration due to the fall of the dead weight. The penetration of the DCP set (upper rod - coupling piece - lower rod) is facilitated by a cone-shaped end piece. Figure 1 shows DCP details.

The DCP device is made in Brazil, and the one used in this research is equal to the TRD model and has the following features:
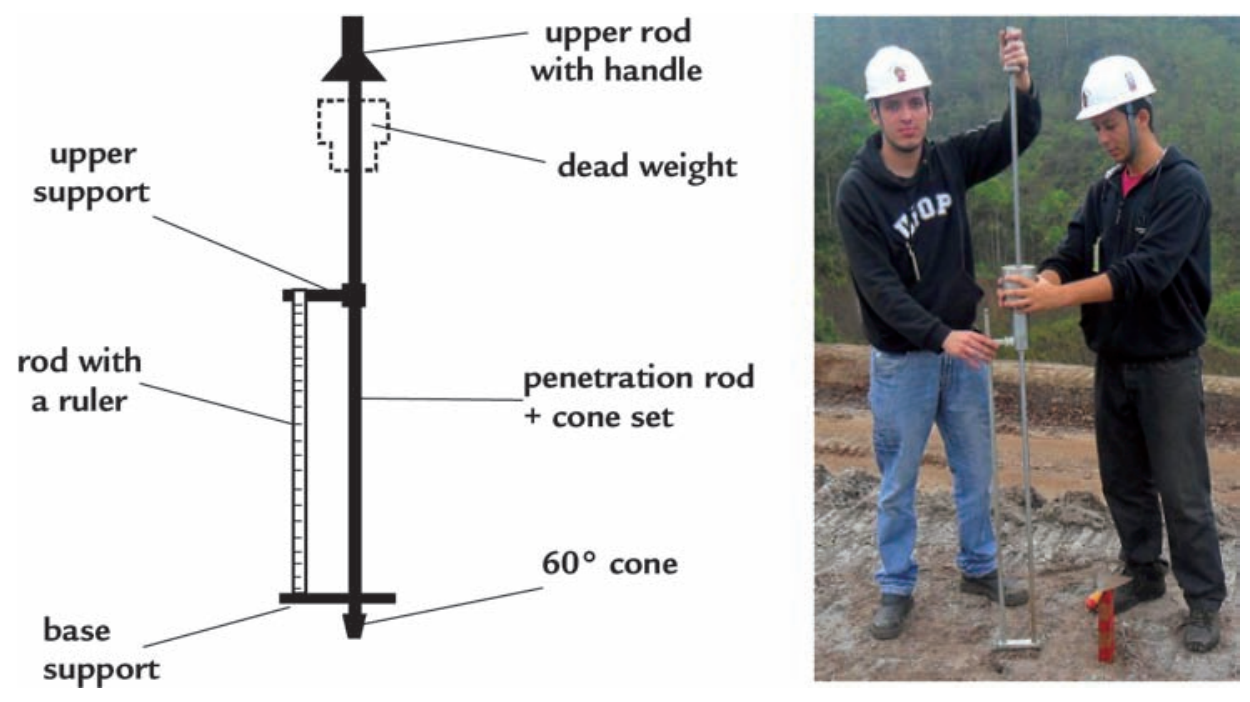

Based on those results a rod penetration versus blow count curve is drawn (Carvalho, 2005).

The DCP test provides a resistanceto-penetration indicative of a natural terrain (or a layer in a fill) (Carvalho, 2005). The higher the slopes in the DCP penetration versus blow count curves, the lower the resistance of the test layers. A change in the curve slope means a change in resistance, and likely, in the case of pavement, a change of layer. However, Lima (2000) called attention that a change in resistance could have other sources, such as a change in water content, alterations in the compaction state or a change of material. All these features can be considered for the compaction control of a fill, including the sand tailings dams addressed herein.

\section{Compaction control}

Ten are the number of points where DCP tests were performed during the dike construction, distributed as shown schematically in Figure 2: six along the dike (points 1, 2, 3, 4, 5 and 6) and four in a dike cross section at the dam center (points A, B, C e D). Point E, located at the beach area, was chosen for comparison

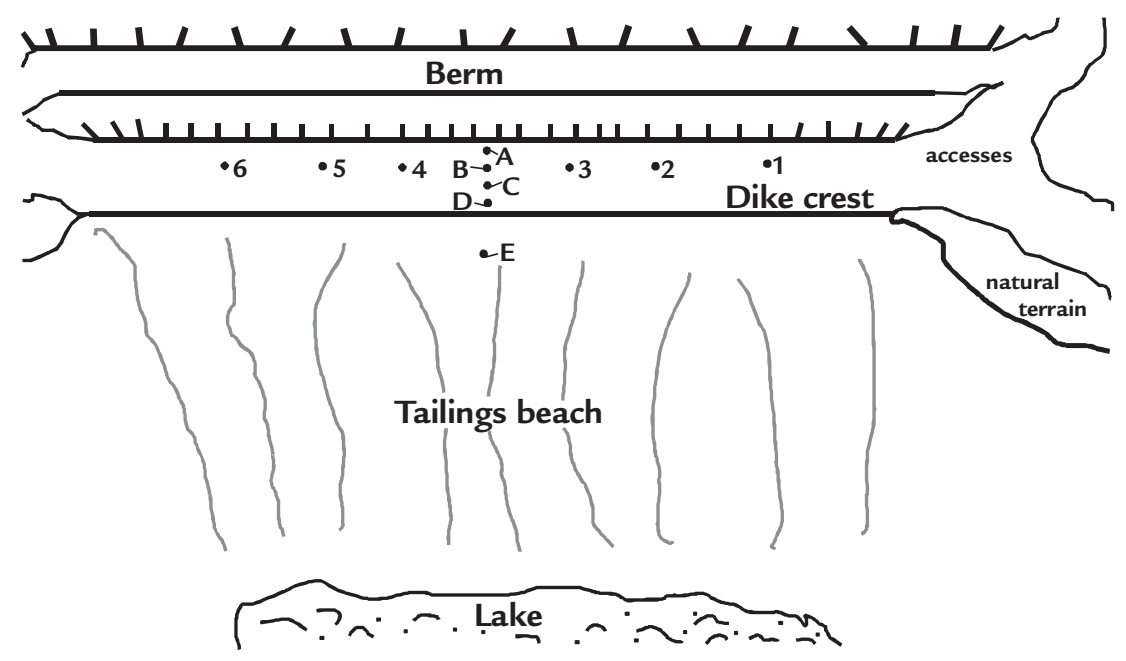

matters with the values obtained in the compacted fill (dike).
Figure 2

Schematic location of the DCP and core-cutter tests in the dike. 


\section{Core-cutter tests}

Direct measurement of the in situ unit weight and water content were achieved using the core-cutter technique. The option for this kind of test instead of others (sand flask, air balloon, nuclear density, etc.) is due to its practicability and speediness, besides giving trustful and representative values.

The core-cutter method uses a resistant cylinder with thin walls and known dimensions, which is pressed into the soil to be tested. One of its borders has a beveled edge to improve penetration, which is also facilitated by partial

\section{Results}

Collected data from quality control analysis based on the core-cutter measurements and overall geotechnical characterization of the compacted fill are presented in Table 1.

The analysis of the results shows that the compaction obtained in the dike seems to be satisfactory for typical specifications requirements as revealed by the core-cutter numbers and subsequent calculations (e.g. degree of compaction higher than $96 \%$ ).

Table 1

Core-cutter, geotechnical characterization, and compaction control average results for the constructed dike.

Figure 3

DCP results at different points at the dike crest (in construction). removal of the lateral confinement material. Once fully embedded, the set composed by the cylinder and the inside material is carefully removed in order to preserve as much as possible the in situ soil fabric, and then trimmed on the borders with a ruler or a spatula. From the core contents, mass is measured and by simple calculations, the bulk density is determined, since the volume is known. The material is then placed in an oven $\left(100-105^{\circ} \mathrm{C}\right)$ to obtain its dry density (as well the in situ water content).

In this research, a PVC cylinder

However, the average placement water content $(7.5 \%)$ presents a value below the optimum water content (14.2\%). Thus, potentially, an increase in the tailings water content would cause a gain in dry densities, or that result could be used to justify a decrease in the dozer passages in case one wants to keep similar degree of compaction.

DCP results for the dike compaction control alternative are presented with the following dimensions was used: $70 \mathrm{~mm}$ height, $71 \mathrm{~mm}$ diameter, $2 \mathrm{~mm}$ thickness and total volume of $277.14 \mathrm{~cm}^{3}$.

Material was also collected for basic geotechnical and mineralogical characterizations in the laboratory. A compaction curve with Proctor normal energy, a grading curve using the laser granulometer Cilas 1064 and the index properties, such as minimum and maximum void ratios according NBR 12004 (ABNT, 1990) and NBR 12051 (ABNT, 1991), respectively were then obtained. in Figure 3 for all tests performed at the site. Leaving aside the initial DCP values between 300 and $400 \mathrm{~mm}$ depth, which correspond roughly with the loose design layer thickness, three DPI ranges (penetration/blow count) can be identified. Thus, points 2, 6, $\mathrm{C}$ and $\mathrm{D}$ present an averaged 30-blow count for the total cone penetration $(850$ to $900 \mathrm{~mm})$ or an average DPI of 30 ; points $5,1,4$, A e B sum an

\begin{tabular}{|c|c|c|c|c|c|c|c|c|c|}
\hline \multicolumn{3}{|c|}{ Core-cutter } & \multicolumn{2}{|c|}{ Proctor Normal } & \multirow[b]{2}{*}{$\begin{array}{c}\text { Relative } \\
\text { gravity } \\
\text { density }\end{array}$} & \multicolumn{2}{|c|}{ Compactness } & \multicolumn{2}{|c|}{ Compaction Control } \\
\hline $\begin{array}{l}\text { Bulk } \\
\text { density } \\
\left(\mathrm{g} / \mathrm{cm}^{3}\right)\end{array}$ & $\begin{array}{l}\text { dry } \\
\text { density } \\
\left(\mathrm{g} / \mathrm{cm}^{3}\right)\end{array}$ & $\begin{array}{c}\text { Water } \\
\text { content } \\
(\%)\end{array}$ & $\begin{array}{l}\text { Max. dry } \\
\text { density } \\
\left(\mathrm{g} / \mathrm{cm}^{3}\right)\end{array}$ & $\begin{array}{c}\text { Optimum } \\
\text { water } \\
\text { content } \\
(\%)\end{array}$ & & $\begin{array}{l}\text { Max. } \\
\text { void } \\
\text { ratio }\end{array}$ & $\begin{array}{l}\text { Min. } \\
\text { void } \\
\text { ratio }\end{array}$ & $\begin{array}{c}\text { Relative } \\
\text { compaction } \\
(\%)\end{array}$ & $\begin{array}{c}\text { Compaction } \\
\text { degree } \\
(\%)\end{array}$ \\
\hline 1.81 & 1.68 & 7.5 & 1.74 & 14.2 & 2.90 & 0.89 & 0.65 & 69.0 & 96.5 \\
\hline
\end{tabular}

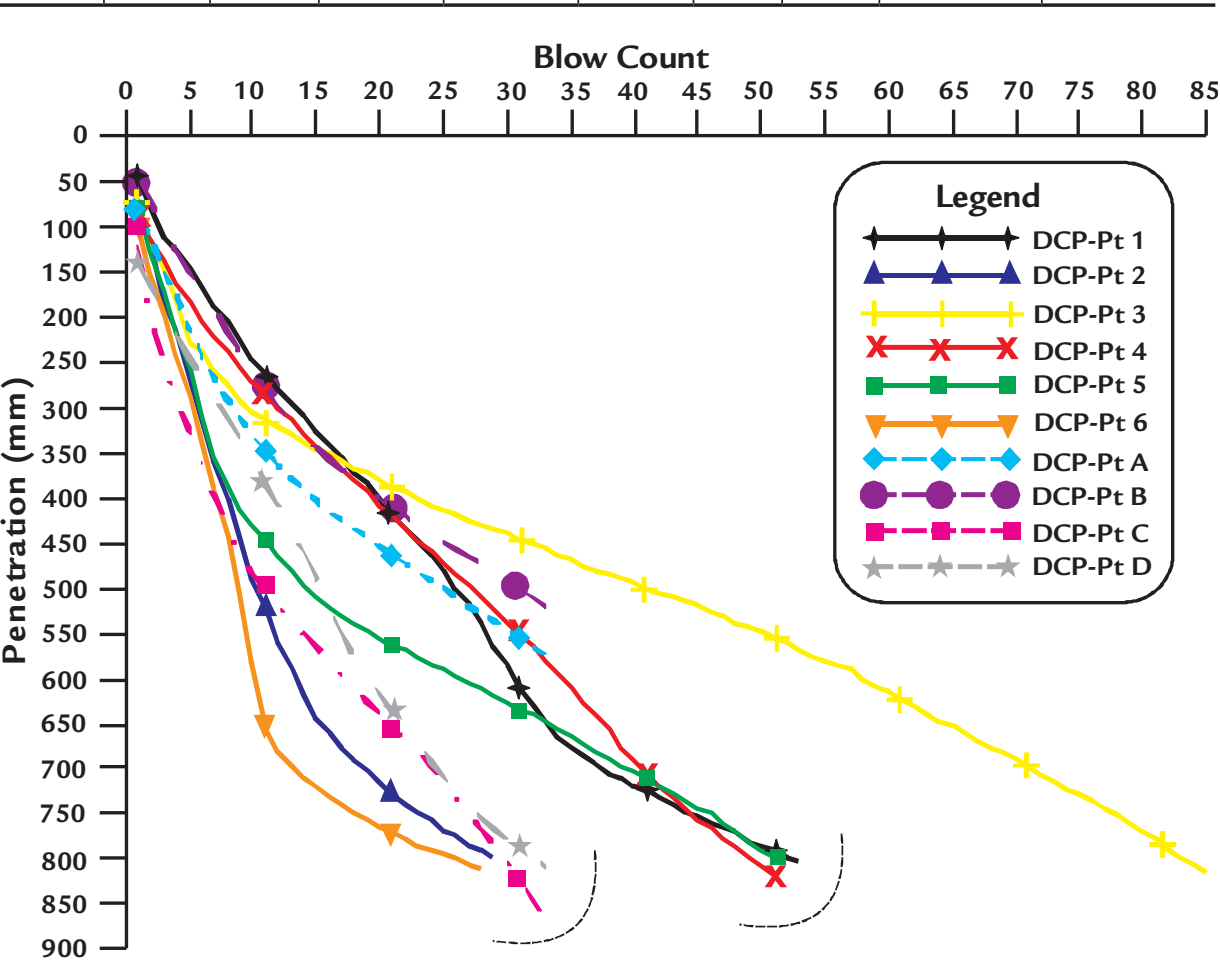


averaged 50-blow count till the depth between 800 and $900 \mathrm{~mm}$ (DPI $\approx 18$ ); and point 3 presents a DCP of 83 blow counts at the $850 \mathrm{~mm}$ depth (DPI $\approx$ 10). This apparent lack of homogeneity in compaction and resistance may be explained by coverage irregularity in the dozer passages or differences in the placement water content. Nevertheless, supposing that DPI values lower than

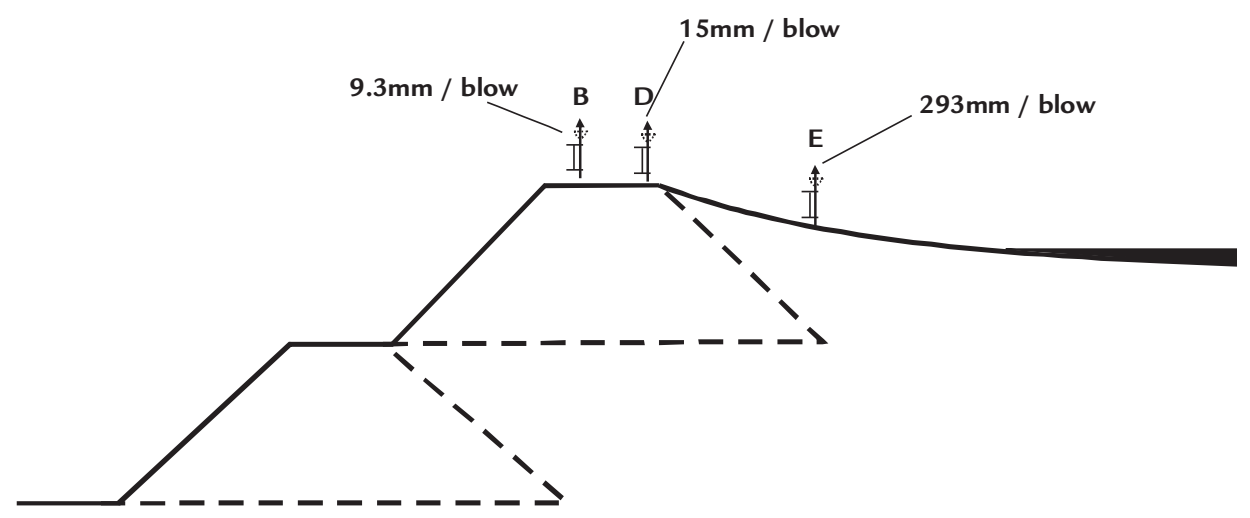

30 are satisfactory for a compacted fill of a dam, as demonstrated by Resende (2012) who established a relationship between DPI and void ratio (relative density), this dike construction would meet requirements and, therefore, the job would be accepted. This is the same conclusion as that obtained with the traditional core-cutter method.

To show the construction effective- ness, a comparison between the dike and the tailings beach level of densification is highlighted in Figure 4 using the DCP results. It is apparent the considerable difference shown by the respective DPI values (penetration/blow) which could be ascribed to the diverse material formation: compaction, for the dike, and hydraulic discharge and sedimentation for the tailings beach.

Figure 4

Comparison between DPI

values at the dike and at the beach.

\section{Conclusions}

The DCP penetrometer (Dynamic Cone Penetrometer) was introduced as an alternate test device for the compaction control of tailings dams raised by the upstream method and using iron ore sand tailings.

It was shown that the DCP test can easily identify changes in resistance inside a compacted fill. In the case study, three different ranges of resistance to penetration were identified all over the test points scattered in the dike. The changes were related to variations in the construction method, especially the number of dozer passages and placement water content.

\section{Acknowledgments}

Authors are grateful to CAPES by the funding grant conceded to the first Author, to Samarco Mineração S.A. for
The use of the DCP for compaction control was presented by setting a certain maximum penetration per blow count (DPI). In the case study, it was verified that compacted layers presented a maximum DPI value of 30 . If this number can be considered satisfactory (according to previous work reported in literature), the compacted layer would be accepted.

Comparisons between DCP and the traditional method of compaction control called core-cutter were made, which allowed for an easy passage from one method to the other.

Overall, quality assessment of the dike compaction was found to be sat- isfactory, as revealed by the core-cutter results and also confirmed by the DCP values. However, the average in situ water content of $7.5 \%$ represents a value well below the optimum water content $(14.2 \%)$. This result suggests that higher dry densities would be reached if there was an increment in the field water content.

Finally the authors are convinced that the DCP test provides an interesting alternative to assess compaction quality control during construction of staged tailings dams because of its proved qualities: rapidness, low cost, accuracy, and practicability.

in the field testing.

\section{References}

its support in the experimental part of this research and to the undergraduate students Luciano and Cáiron in their help
. 
LIMA, L. C. DCP test applied on compaction quality control of road works performed in fine lateritic soils. São José dos Campos: Aeronautics Infrastructure Engineering - Airport Infrastructure Area - Aeronautic Institute of Technology (ITA), 2000. (MSc. Dissertation). (In Portuguese).

RESENDE, L. R. M. Bearing capacity of beach tailings dams and construction of embankment fills. Ouro Preto: Department of Mining Engineering, Federal University of Ouro Preto (UFOP), 2012. (MSc. Dissertation). (In Portuguese).

Artigo recebido em 21 de janeiro de 2012. Aprovado em 06 de maio de 2013. 